\title{
Louise Vilioen André P. Brink in gesprek met Louise
}

Louise Viljoen is hoof van die

Departement Afrikaans en Vilioen

Hierdie gesprek met André P. Brink is in November 2004 gevoer in antisipasie van sy sewentigste verjaardag in 2005 en is iets van 'n terugkyk oor verskillende aspekte van sy formidabele loopbaan as skrywer en literator. Omdat dit onmoontlik is om in die kort bestek van 'n gesprek soos hierdie al die aspekte van sy uitgebreide oeuvre te dek, val die fokus veral op sy werk as romanskrywer, dramaturg, kritikus en akademikus.

André, soos jy weet word hierdie onderhoud gevoer vir plasing in die nommer wat Tydskrif vir Letterkunde aan jou en jou werk gaan wy by geleentheid van jou sewentigste verjaardag in 2005, 'n soort Festschrift of huldigingsnommer. Ek het 'n keer gehoor dat 'n kollega in België praat van die oude mannen-boek wat sy kollegas en vakgenote vir hom gemaak het: dis vir my nogal 'n mooi woord.

Hulle het in Holland ook die gewoonte om vir jou'n speculaas-koek te gee, maar dié kry jy vroeg al as jy vyftig word. Ek onthou Eleanor Baker het vir my destyds een gestuur uit Holland uit en dit het in duisend klein stukkies hier aangekom. Ek dink hulle noem dit'n Abraham of iets: Hij heeft Abraham gezien.

Sewentig is inderdaad ' $n$ belangrike mylpaal in ' $n$ formidabele loopbaan wat - anders as in die geval van die meeste oude mannen - duidelik nog veel gaan oplewer. Ek wil begin deur iets te vra oor die taal waarin jy skryf. Jy is een van die min skrywers in Suid-Afrika wat met ewe veel gemak in Afrikaans en Engels kan skryf. Op watter punt het jy begin om tegelyk in Engels en Afrikaans te skryf en hoe beïnvloed dit die hele proses van skryf? Wel, dit was eintlik noodgedwonge met die verbod op Kennis van die aand toe ek skielik nie meer'n leserspubliek gehad het nie. Op daardie tydstip het ek nie geweet of my volgende boeke toegelaat gaan word nie of nie. Om te oorleef het ek toe begin om ook in Engels te skryf. Dit was aanvanklik met die hulp van 'n paar Engelse vriende wat vir my 
elke duim van die pad moes lei, want komende van die Vrystaat was my Engels maar redelik wankelrig op die bene, al het ek Engels as hoofvak op universiteit gehad. En baie gou, teen die tyd dat ek by ' $n$ Droë wit seisoen gekom het, maar miskien was dit al by Gerugte van reën, het dit so deel geword van my manier van skryf dat ek nie meer daarsonder wil nie. Dit is natuurlik nie meer nodig nie, maar nou kan ek eintlik nie anders nie, want elke taal is amper soos ' $n$ venster met' $n$ ander kleur glas waardeur jy na'n bepaalde toneel kyk. Dit is die fassinering met die anders-maak en anders-lyk van die wêreld as gevolg van die feit dat jy'n ander taal gebruik, wat maak dat ek heeltemal versot geraak het daarop en eintlik nie meer anders kan of wil nie. Daarom voel ek het ek nie eintlik veel van'n keuse nie; ek wil en ek moet so aangaan.

Dit maak amper jou wêreld met' $n$ hele taal groter.

O beslis; daar is ook die ou holruggeryde gesegde: "Soveel tale as ek kan, soveel male ben ek man". Daar is ook'n praktiese oorweging daarby: ek het die neiging om baie vinnig te werk, want wanneer ek met iets begin - veral as dit by skryf kom - wil ek dit uit my uit kry. Daarná begin die eintlike werk, die oor en oor en oor hersien, maar ek kan die spanning en die druk daarvan nie verduur terwyl dit aan die gang is nie, so ek wil dit uit my uit kry. Dan kan ek geneig wees om kortpaaie te kies, maar as ek dan die hele ding weer moet oordoen in 'n ander taal dan ontdek ek dat ek hier baie beslis die maklike uitweg gekies het of daar verval het in my eie stel clichés. Dan moet ek weer daaroor dink en dit anders stel. Dit werk natuurlik weerskante toe, want as ek in taal A begin (want ek begin nie altyd in dieselfde een nie) en dit dan oordoen in taal B, ontdek ek dinge wat ek gemis het in taal A. Dan gaan ek terug soontoe en tel hulle op - en in daardie proses ontdek ek dan weer dinge wat ek misgekyk het in taal B. So kan dit eintlik onbepaald aanhou tot ek op'n bepaalde tydstip net moet besluit: nee, ho, nou's dit genoeg.

Voel jy dat jy op hierdie manier ontkom aan die spanning wat daar in SuidAfrika bestaan tussen Engels óf Afrikaans?

Ja, dis noodgedwonge, want Engels bly selfs nou nog my tweede taal. Ek voel net tuiser in Afrikaans, maar as jy soos in my geval die skryf daarvan aangeleer het as ' $n$ manier om te oorlewe, dan raak jy darem meer ingeburger. Ek kan byvoorbeeld nou sê dat ek letterlik in altwee tale kan droom. 
Hoe voel jy oor die debat wat binne die groter Afrika-konteks bestaan oor tale soos Engels wat uitheems is aan Afrika. Daar is 'n skrywer soos Ngugi wa Thiong'o wat gevoel het dat hy in sy moedertaal moet skryfeerder as in die eertydse koloniale taal Engels. Voel jy dat tale soos Engels en Frans al inheemse tale in Afrika geword het?

Ek dink so. Dit het al vanaf die verskyning van The Empire Writes Back duidelik geword dat die eertydse koloniale tale heeltemal ingeburger geraak het. Engels soos wat dit in Kenia of in Nigerië of in Suid-Afrika gebruik word, is doodgewoon nie die Queen's English nie. Dit het geleer om Afrika te sê. Ek dink ek kan verstaan waarom Ngugi gedoen het wat hy gedoen het, maar ek is tog'n bietjie geamuseer daardeur dat hy dit eers begin doen het toe hy seker was dat wat hy ookal in Kikuyu skryf onmiddellik in Engels vertaal sal word. Daar is ' $n$ psigologiese rede agter sy optrede wat ek heeltemal aanvaarbaar vind omdat die inheemse tale onder die druk van die eks-koloniale tale net eenvoudig mag verdwyn. Ons sit op die oomblik met die probleem dat daar amper nie publikasie-geleentheid is vir Zulu of Xhosa of Sotho nie en dit kan ernstig word. Daarom dink ek dit sou 'n goeie ding wees as sê maar skrywers soos Ndebele en Zakes Mda ook in hulle moedertale begin publiseer. Ek dink hulle het die Ngugi-stadium bereik waar hulle nie hoef te twyfel daaroor dat hulle werk in ander tale beskikbaar gestel sal word nie.

Hoe is jy as skrywer beïnvloed deur die feit dat die Afrikaanse literêre establishment so krities teenoor jou werk gestaan het en dat hulle eintlik eers - as ek dit reg lees - met Duiwelskloof begin het om toekennings te maak aan jou werk?

Ek is nogal geamuseer daaroor. Ook deur die keuse van juis Duiwelskloof, want die enigste werk voor Duiwelskloof wat verbasend gul deur die Afrikaanse establishment ontvang is, was 'n Droë wit seisoen. Ek dink daar was iets van die Afrikaner se voorliefde vir foltering daarby betrokke, want dit is tog nie' $n$ baie mooi beeld van die Afrikaner wat in een van daardie twee romans na vore kom nie. Ek kan nie sê dat ek dit gebruik het as' $n$ barometer nie, maar ek het' $n$ bietjie ongemaklik begin voel toe Afrikaanse establishment-mense begin het om amper klakkeloos en selfs geesdriftig te aanvaar wat ek skryf. Dit het natuurlik ook te doen met die hele verandering wat in die land gekom het na 1994: ons wil tog so graag bewys dat niemand van ons ooit pro-Apartheid was nie, dat ons eintlik almal altyd saamgedink het. 
Dink jy'n skrywer kan gestimuleer word deur' $n$ konflikverhouding met die literêre establishment? Dink jy dit is miskien selfs nodig dat skrywers nie alte gou op die hande gedra word nie?

Ek sal miskien te maklik sê dat dit nodig is omdat dit is hoe ek gevorm is. Maar die spanningsverhouding was vir my waardevol. Dit is nie dat 'n mens uit moedswilligheid in konflik kom met die establishment nie (daar moet seker soms 'n tikkie moedswilligheid by kom). Jy word gekwets en ek weet nie of jy opsetlik probeer terugkwets nie, maar jy pull nie punches nie. Ek dink in daardie gevegsituasie word 'n mens gedwing om drie maal te dink wat jy sê: gaan dit reg opgeneem word, gaan dit doelbewus mense ontstel want jy wil dit ook nie onnodig doen nie. So jy is baie seker dat dit is wat jy wil sê. Verder is dit nou maar eenmaal die vreemde paradoksale geval dat skrywers eintlik meer floreer in so ' $n$ konfliksituasie as wanneer alles lekker rustig en ontspanne gaan. Ek kan nie heeltemal sê soos dit nou gaan nie, maar op'n manier tog wel want alles gaan maar. Ek sien daar is'n ou wat vanoggend weer in Die Burger so kla oor die manier waarop Die Burger vloekwoorde gebruik, veral teen vroue. Daar is dikwels iets van 'n tienerhouding daaromtrent: ek kan kwaaier vloek as jy, maar niemand gee eintlik om daaroor nie. Op die oomblik is daar natuurlik weer'n soort bedreigde gevoel, dink ek ten onregte, by baie Afrikaners. Dit mag miskien die taal goed doen, maar ek is net so bekommerd oor baie van die houdinge wat saam met die gevoel oor die taal gaan.

Ek het nou onlangs ' $n$ artikel gelees oor die oorhandiging van die Bookerprys wat' $n$ soort gala- of Oscar-geleentheid geword het. Hoe voel jy as skrywer oor literêre pryse in die algemeen?

Ek dink ons is almal maar so' $n$ bietjie lief vir geld. Dit is baie lekker om 'n prys te kry, maar ek dink'n mens moet'n groot sak sout daarmee saam neem omdat jy besef dit is die smaak van die drie of vyf persone wat op die komitee sit. Verder mag daar soveel politiek agter die skerms - en partykeer nie eers agter die skerms nie - aangaan dat' $n$ mens jouself nooit te ernstig moet opneem nie. Maar dit is baie lekker om dit te kry: ek dink nie enigiemand kan dit ooit ontken nie. Ek dink selfs ons kan doen met nog'n paar Afrikaanse of Suid-Afrikaanse literêre pryse.

En die hele verskynsel van literatuur as spektakel of as 'n soort sirkus - hoe geval dit jou?

Dit begin al met die publikasie van' $n$ werk. Deesdae kan jy eintlik nie 'n boek publiseer sonder om om die uitgewers se onthalwe' $n$ promosie- 
veldtog aan die gang te sit nie. En dit is vir my die moeilikste, amper die onverduurbaarste, deel van skryf. Daardie openbare spektakel is werklik nie lekker nie. Ek wil nog die skrywer teëkom wat daarvan hou. Ek dink iemand soos Rushdie geniet dit nogal, maar meestal voel die mense verskillende grade van ongemak tot diep ontsteltenis daaroor. Dit is egter maar min wat jy kan optree soos die Elfriede Jelinek van Oostenryk wat nou die Nobelprys gewen het: sy het mos gesê sy gaan dit nie haal nie en ou Beckett het gesê hy kan hulle nie keer om dit aan hom te gee nie, maar hulle kan hom nie dwing om dit te gaan haal nie. 'n Mens doen dit eintlik maar om die uitgewers se onthalwe want jy voel jy't'n soort verpligting teenoor hulle. En gegewe die manier waarop die wêreld ontwikkel het, kan dit eintlik nie sonder reklame nie tensy jy een van die rares is soos John Coetzee wie se reklame daarin lê dat hy nie reklame doen nie. Ek dink dit sal baie ontsteltenis veroorsaak, nie net vir hom nie maar vir baie ander mense, as hy begin om gewoon op promosietoere te gaan. Dit sal die hele mistiek van John Coetzee wegneem.

Daar is eintlik iets onversoenbaar aan die praktyk van skrywer-wees wat soveel nougesetheid en afsondering verg en hierdie openbare proses.

Absoluut. Sonder die isolasie kan jy nie skryf nie. Maar juis daarom is daar naas die weersin' $n$ mate van aantrekkingskrag in die openbare spektaktel: dit gee jou kans gee om uit jou dop uit te kom, om kontak te maak met regte lesers. As skrywer word jy nog elke keer met' $n$ bietjie ongeloof geslaan by die gedagte dat daar tog inderdaad mense is wat reageer op dit waarmee jy in jou eentjie sit en baklei het. In daardie opsig is daar iets werklik hartverwarmends omtrent die hele proses.

Gepraat van lesers, was daar ooit enige kritici hier of oorsee wat jou werk beïnvloed het deur wat hulle gesêhet, wat jy voel werklik jou rigting bepaal het?

Ek dink aan die begin of feitlik aan die begin toe ek met erns begin publiseer het, was iemand soos Rob Antonissen vir my 'n absoluut onmisbare stem. Toe hy veels te vroeg kanker gekry het en dood is op ouderdom 52, was dit vir my asof 'n werklike steun weggeval het. Gelukkig het ek dit so getref dat daar altyd ten minste een persoon was in wie se oordeel ek' $n$ volstrekte, amper vraaglose, vertroue gehad het. $\mathrm{Na}$ Rob - daar was'n paar jaar van'n hiaat - was daar Tim Huisamen in Grahamstad wat genadeloos kon kritiseer en ook met die wonderlikste positiewe voorstelle kon kom. En dit is min wat jy daardie twee kry, 
want mense het óf ' $n$ soort agting óf ' $n$ versigtigheid vir die skrywer wat' $n$ vriend is en hulle wil nie seermaak nie. Maar as hulle nie bereid is om seer te maak wanneer dit regtig nodig is nie, dan help die kritiek eintlik nie. In die negentigerjare het ek'n paar jaar lank tot met Duiwelskloof, vanaf Die kreef raak gewoond daaraan,'n editor van die ou skool by my uitgewer in Engeland gehad wat ongelooflik was. Hy [John Blackwell] het nét nie'n komma of punt misgekyk nie en jy moes kon verantwoord waarom dit'n punt en nie' $n$ komma was nie. Hy het jou ook baie goed laat verstaan as dit nou rêrig nie' $n$ goeie idee is om iets in die boek te hê nie. Hy het my byvoorbeeld uit Kreef seker 300 bladsye laat sny - goddank ook, want dit is klaar baie lank soos wat dit is. Hy is skielik dood in die middel van Duiwelskloof: ek het nog altyd baie skuldig gevoel daaroor, ek dink dit was vir hom net te veel gewees.

Dink jy daar is nog baie van hierdie old school editors?

Baie, baie, baie min. En ek weet nie of daar regtig 'n skrywer is wat heeltemal daarsonder kan doen nie. Jy het net' $n$ klankbord nodig.

Jy is ook'n akademikus en goed op hoogte met al die filosofiese denkrigtings en teoretiese ontwikkelinge wat literatuur beïnvloed vanaf die eksistensialisme tot by die postkolonialisme. Jy kon altyd alles baie goed vertolk as kritikus en resensent, maar wat was ingrypend vir jou as skrywer? Watter een van hierdie filosofiese of teoretiese rigtings het jou werk as skrywer die sterkste beïnvloed?

Dit is nie so maklik om dit te beantwoord nie, want op die een vlak het ek nog altyd gevind dat die twee mekaar geweldig maklik kruisbestuif. Aan die ander kant kon ek ook weer - miskien gebeur dit as jy deur apartheid gevorm is waardeur jy aparte kompartement vir jou denke ontwikkel - die teorie as teorie wegbêre wanneer ek skryf. Ek dink die eksistensialisme het my ontsaglik beïnvloed, miskien omdat ek jonk en baie ontvanklik was en ek op die tydstip dat ek Frankryk toe gegaan het nie al my normale veiligheidsboeie kon gebruik nie. Daarna was dit dinge wat soort van gekom en gegaan het; daar was nie een -isme of rigting wat my permanent bly beïnvloed het nie. Ek dink iemand soos Eco se manier van kyk na die semantiek het my nogal gestimuleer en ongetwyfeld ook Derrida, alhoewel ek taamlik gou weggebreek het van die idee dat alles heeltemal lukraak is. Die idee dat jy nooit te veel vertroue moet hê in wat die woord kan oordra nie, was egter tog een van die vrugbaarste invloede op my manier van skryf. 
Wat vir my ook interessant is as ek dink aan jou werk en dié van John Coetzee is dat die soort romans wat julle al in die sewentigerjare geskryf het eintlik die ontwikkeling van die postkoloniale teorie in die tagtigerjare vooruitgeloop het. Waaraan sou jy dit toeskryf? Was dit doodgewoon die situasie in die land wat' $n$ sekere soort interaksie met die geskiedenis van jou gevra het wat daardie teorie geantisipeer het?

Ek dink so. In party gevalle het die werk saam met die teorie ontwikkel, maar ek dink dit kom ook uit die situasie self. Die invloed van die eksisitensialisme het byvoorbeeld gekom uit die feit dat ek in daardie stadium geworpene en vreemdeling in Parys was. Niks was voorspelbaar nie en ek was nie van dag tot dag seker in watter rigting ek aan die beweeg was nie. Ek het die eksistensialisme geleef: dit hoef nie via filosowe na my toe te gekom het nie. Iemand soos Camus het dit versterk omdat hy vir my kon sê, maar dis wat jy besig is om te beleef. Met die postkolonialisme was dit in baie opsigte iemand soos Spivak wat my sekere dinge laat ontdek het en saam met Spivak selfs iemand soos sy's nou nie een van die groot teoretici nie - Toril Moi wat vir my'n begrip van feminisme gegee het en wat vir my help kristalliseer het wat daar aan die gang was in my.

Dit is in die literatuurgeskiedenis bekend dat jy vanaf die sestigerjare Afrikaanse lesers bekend gestel het aan' $n$ repertorium van tegniese middele vanaf die bewussynstroom, die gebruik van meervoudige vertellers, raamvertellings, selfrefleksiewe vertellings, metavertellings, ensomeer. Wat my betref, is daar romantegnies gesproke altyd iets aan die gang in jou werk. Is dit vir jou belangrik dat'n skrywer tegnies vernuftig moet wees en dat hy of sy'n hele repertorium van tegnieke moet beheers?

Dit is vir my belangrik dat ek dit moet kan doen. Jy kry skrywers - en sommige van hulle is onder die bestes wat daar is - wat amper op' $n$ soort naïewe, impulsiewe manier inplons in die werk en feitlik doelbewus besinning daaruit hou. Miskien gebeur dit by my meer bewustelik as gevolg van die feit dat ek in die akademie was, maar ek dink dit kom eerder uit'n soort geesdrif vir dinge wat ek die heeltyd aan die ontdek is deur dit wat ek lees. Dit was vandat ek klein was amper tweede natuur wanneer ek' $n$ boek geniet om ook vir myself te probeer vra hoekom geniet ek dit. En dan het dit maar daarvandaan verder gegaan: ek kyk as't ware oor my eie skouer terwyl ek aan die lees is. 
Vind jy ook doodgewoon plesier in die vernuf wat dit verg?

$\mathrm{O}$ ja, want dit is'n spel. Ek dink in daardie opsig is Kundera reg; hy het mos vier opgawes vir die literatuur gehad waarvan die een die ludiese, die speelse, is en ek dink dit is een van die onmisbaarste faktore in die letterkunde. Ongelukkig dink ek is daar nogal heelwat mense - meer onder kritici, maar selfs onder skrywers - wat nie meer daardie plesier het aan die letterkunde nie. Ek het'n plesier in tegniek soos wat ek plesier daaruit put om te sien hoedat'n goeie skrynwerker met'n stuk hout werk, en op hoeveel maniere hy met die grein kan saamwerk of teen die grein kan inwerk. Dit is een van die hoofredes is waarom ek gewoon aanhou met skryf.

Jy het jou deurgaans in jou loopbaan daaroor uitgespreek dat 'n skrywer'n sosiale verantwoordelikheid het en jou eie werk het eintlik meedoënloos volhard daarin om die politieke ongeregtigheid in Suid-Afrika aan te spreek. Sou jy sê die koms van die demokratiese bestel in Suid-Afrika het jou werk in' $n$ ander rigting gestuur as vantevore?

Ek weet nie of dit wesenlik in' $n$ ander rigting gaan nie. Ek dink die een ding wat ek ontdek het die afgelope klompie jare na die verandering is dat ek, soos vele ander skrywers in die land, nie in die eerste plaas teen apartheid ingeskryf het nie, maar teen iets wat agter apartheid lê. Toe apartheid dus begin wankel (en ek dink nie dit is al verby nie), het dit nie sonder meer die mat onder ons voete uitgetrek nie. Ons het nog altyd geskryf teen daardie ander ding en daardie ander ding is vir my die misbruik van mag wat in elke enkele samelewing bestaan. As 'n mens skryf' $n$ bietjie eng sou sien as téén' $n$ bepaalde iets inskryf, is die teiken waarteen ek my rig nie meer in die eerste plaas' $n$ rasse-teiken nie maar 'n gender-teiken. Vir my is die tradisionele patriargale onderdrukking van vroue in alle gemeenskappe in Suid-Afrika - hier geld dit swart net soseer as wit - een van die groot misstande wat ons eintlik misgekyk het omdat rasse-onderdrukking die dringendste probleem was. Indien daar verandering is - en daar is sekerlik' $n$ verandering - lê dit vir my in'n groter spektrum waaroor'n mens kan skryf. Daar is meer wat jy kan sê en wil sê en wat jou begeester en beetneem. Jy voel nie meer in die eerste plaas ingestel op die misstande van ons samelewing nie.

Word jy ooit gefassineer of bekoor deur mag? Ek dink nou aan Foucault wat gesê het mag is ook iets waarvan jy die produktiwiteit moet insien. Ek dink die ou frase "die mag van die woord" wys daarop dat jy deur te skryf jouself begeef op' $n$ terrein waar daar mag uitgeoefen word en 
manipulasie kan plaasvind. Dit mag heerlik wees, maar as 'n mens bewus is van die negatiewe kant wat altyd met mag saamgaan dan hanteer jy dit óf met die tong in die kies óf baie versigtig, want jy besef hoe gevaarlik hierdie ding is en hoe dit jou kan laat struikel.

Na aanleiding hiervan wil ek jou ook vra oor die posisie van die skrywer wat namens iemand anders moet praat. Wat my betrefkan'n romanskrywer namens enigiets of enigiemand praat, maar die oomblik wat jy dit doen, is $j y$ in ' $n$ bepaalde arena en doen jy dit 'n bepaalde historiese en politieke konteks. Hoe het jy dit as romanskrywer hanteer om byvoorbeeld ' $n$ roman te skryf soos Kennis van die aand waarin die ek-verteller' $n$ bruin man is of Houd-den-bek waar jy praat namens ' $n$ verskeidenheid karakters soos byvoorbeeld die slaaf Galant en verskillende vroue? Hoe het jy jou as skrywer geposisioneer en watter tegnieke het jy gebruik om die verantwoordelikheid van so ' $n$ vertelsituasie te hanteer nadat jy daardie eerste verbeeldingsprong geneem het?

Daardie verbeeldingsprong is ' $n$ vermetele sprong, want dit is die basiese daad van vermetelheid waarmee skryf begin. As jy dit nie doen nie, kan jy nie skryf nie. Maar daar is'n sekere magsituasie ter sprake wanneer jy jou indink in die situasie van 'n ander en dan moet jy verskriklik versigtig wees. Dit gebeur veral wanneer' $n$ man vanuit die standpunt van'n vrou skryf: as die man wat in die patriargie die mag het uit'n vrou se hoek skryf, dan kan dit baie maklik net weer wees om haar stem weer weg te neem en namens haar te praat. Dieselfde geld as 'n blanke' $n$ swart of ' $n$ bruin stem aanneem. Ek dink egter dit is nodig dat sommige van dié wat hulle volgens die sosio-politieke opset aan die kant van die mags-establishment bevind, moet demonstreer dat hulle minstens probéér verstaan in watter posisie ander mense hulle bevind anders is daar' $n$ totale skeiding tussen die maghebber en die geëksploiteerde. Daar moet mense wees wat probeer - al slaag dit nie altyd nie - om daardie kloof te oorbrug: om te wys daar is darem mans wat probeer verstaan in watter situasie die vrou haar bevind of daar is darem wit mense wat probeer verstaan wat dit beteken om swart te wees, al kan ons nooit regtig in die grond in weet wat dit beteken nie.

Bakhtin het geskryf dat die roman dié medium is waarin veelstemmigheid verwesenlik kan word, waarin die sentrale vertellende outoriteit se monoloog uitgedaag kan word deur die diskoerse van sy karakters. Is dit jou ondervinding as skrywer dat die diskoers van ' $n$ karakter wat jy geskep het jou monoloog begin infiltreer en jou outoriteit as skrywer begin ondermyn? 
O ja, en dit is vir my ook een van die dankbaarste dele van skryf, die ou ding van karakters wat begin terugpraat. Ek dink ek was die eerste keer werklik bewus daarvan in ' $n$ Oomblik in die wind waar Elisabeth net op 'n gegewe moment gesê het maar jy is nou besig om vir my in'n rigting te probeer stuur en ek vat dit nie: ek gaan nie so wees nie, ek gaan dit nie sê nie. Dit was'n wonderlike interaksie wat die heeltyd met haar aan die gang was deur die skryf van die werk. Ek sal amper wil sê as dit nie taamlik vroeg in' $n$ roman gebeur nie, dan begin ek voel ek moet dit maar liewer los. Dit is nou as die karakters werklik begin om hulle eie loop te neem en hulle eie stemme teen my stem in te gebruik-amper skouspelagtig moes dit gebeur in Houd-den-bek waar, wat ek ook al sou wou doen en selfs ook wat die geskiedenis deur die argiefdokumente vir my sou wou voorsê, dit nie noodwendig was wat die karakters wou doen nie. Teen al die getuienis wat in die hof gelewer is en in die argiewe lê, moes die karakters hulleself kon manifesteer en moes hulle kon wees wie hulle wil wees. Op'n gegewe moment in die verloop van die verhoor het die regter byvoorbeeld die hof leeg gemaak en gesê daar is sekere stories wat die rondte doen oor Galant en Hester. Hy het gesê hy wil eers daarna luister, maar dit is nie vir die publiek bedoel nie en dit is dus ook nie in die argiefdokumente nie. Waar wil jy nou 'n vrugbaarder prikkel vir die verbeelding hê as so iets; ek dink dit was eintlik daardie - Derrida sou geglimlag het hieroor - afwesigheid wat die hele roman laat gebeur het. Dit móét kan dat die karakter teen jou in praat.

Kry karakters wat jy as negatief sou kon tipeer soos byvoorbeeld die hoofkarakter in Gerugte van reën ook'n soort houvas op jou?

$\mathrm{O}$, geweldig. Dit is eintlik seker asof jy deur die bose besete raak (soos in Opperman se “Kuns is boos"); jy moet werklikwaar kan verstaan wat'n onplesierige of 'n walglike mens dryf en jou in alle gedaantes kan uitstort om te hoor wat hulle te sê het om te probeer verstaan. Jy hoef nie die moordenaar te vergewe dat hy' $n$ moordenaar is nie, maar jy kan verstaan wat hom'n moordenaar gemaak het. Daar is egter sommige uiterstes: ek dink hier aan die verkragting van babas en so aan. Dit sou vir my donners moeilik wees om so' $n$ karakter te skep en werklik te probeer verstaan, want daar is soveel weerstand in myself teen so iets. Maar ek dink as' $n$ mens regtig wil beskryf, moet jy dit kan oorweeg.

Bakhtin het ook die stelling gemaak dat die roman die veelstemmige genre is en dat die drama - hy verwys veral na die ou tragedies - eintlik monologies 
is in die sin dat die sentrale beheer daar sterker is. Jy skryf romans én dramas: dink jy daar is werklik' $n$ wesentlike verskil tussen die twee genres wat dit betref?

Ek sou nie' $n$ wesenlike verskil daar sien nie. Ek dink jou vermoë om jou in te dink in die vel van iemand anders is soveel meer op die spits gedryf in die drama. Jy sou miskien van die roman kon sê dat jy in jou hantering van die verskillende karakters voorkeur kan gee aan die een en die ander so ' $n$ bietjie afskeep, maar dit gebeur in die drama ook maar. Jy moet egter weet wat in die binneste binneste van Macbeth én sy vrou én die hekse én Banquo aangaan, al word Macbeth in die sentrum gestel. Die manipulasie bly eintlik maar dieselfde, want daardie vermetelheid van die begin om jou te durf indink in iemand anders se lewe is basies dieselfde.

Ek wil nou vra of jy dink jy sal weer dramas skryf, maar dit gaan gepaard met die vraag of 'n mens so "maklik" 'n drama begin skryf as wat jy 'n roman begin skryf. Is dit' $n$ individuele besluit of is dit afhanklik van jou interaksie met spelers, met regisseurs, met borge, met opdraggewers? Sou jy 'n drama begin skryf sonder dat jy weet daar is die potensiaal om dit uiteindelik op te voer?

Ek dink nie jy sou maklik kan nie; ek sal nie kan nie. Dis hoekom ek opgehou skryf het in die sewentigs. My situasie was anders as dié van iemand soos Athol Fugard wat nie afhanklik was van'n amptelike teater nie en wat sy groep spelers gehad het met wie hy die hele tyd kon saamwerk sodat hy geweet het dit gaan opgevoer word. Ek het toegang tot die Rhodes Teater gehad, maar dit beteken jy kan miskien een stuk ' $n$ jaar doen met ' $n$ groepie studente en dan was dit in elk geval in Engels, alhoewel ek tog 'n paar goed in Afrikaans met hulle gedoen het. Ek was in werklikheid aangewese op die staatsgesubsidieerde teater en dit was 'n wesentlike gevaar dat die produksie weggeneem kan word as een persoon in die gehoor beswaar maak teen die drama. Dit het gebeur met' $n$ produksie wat ek van Chris Barnard se Taraboemdery gedoen het. Uiteindelik het dit vir my op 'n keuse afgestuur. Ek het geweet as ek' $n$ roman skryf, kan dit verbied word maar teen daardie tyd het ek die middele gehad om te sorg dat hy dan ten minste oorsee sou verskyn. In die geval van'n drama was daar geen sekerheid nie en omdat 'n mens jou kreatiewe energie effektief wil gebruik, het ek doodgewoon die drama gelos. Ek het eers weer met Die jogger teruggekeer na die drama, maar dit was ook' $n$ baie spesifieke storie. Daar was' $n$ konferensie in Salzburg in die negentigs en om die een of 
ander rede het hulle vir my saam met Arthur Miller en twee ander genooi om meesterklasse in drama te kom gee. Waarom hulle my vir drama gekies het, weet die Here alleen, maar dit was'n ongelooflike geleentheid waar ek'n week lank saam met die mense kon werk en weer al die hartstog wat ek eintlik vir die drama het en wat begrawe geraak het, kon voed. Toe ek daar uitkom, het ek net geweet ek moet terug teater toe en toe het ek Die jogger geskryf. Van toe af wil ek nog altyd weer en ek dink ook ek sal; ten spyte van al daardie voorwaardes dink ek tog dat ek'n drama sou skryf as die regte storie kom ongeag of ek weet of dit opgevoer sal word of nie.

Om weer terug te keer na jou oeuvre as romanskrywer: heelwat van die reaksies op jou jongste roman Voor ek vergeet het daarop gewys dat dit' $n$ element van self-refleksie, self-verwysing, selfs self-parodiëring bevat. Dink $j y$ dit is nodig dat' $n$ skrywer wat so 'n uitgebreide oeuvre soos jy opgebou het op hierdie wyse daarna terugkeer of moet jy jouself losmaak van jou eie geskiedenis as skrywer?

Dit is 'n baie interessante vraag. Ek sou nooit kon terugkeer in die sin dat ek weer die goed moet lees nie. Dit het af en toe gebeur dat ek vir'n nuwe uitgawe ' $n$ boek weer moet persklaar maak of so iets. Dit was nogal vir my vreemd, want' $n$ mens sterf so ver af daarvan. Aan die een kant is daar nogal' $n$ soort vreugde daarin dat jy in sommige opsigte ontdek dis nie heeltemal so sleg as wat jy gedink het nie en in ander opsigte ontdek jy, my Here, dis eintlik baie slegter as wat jy gedink het. So in daardie sin, terugkeer nee; maar ek dink'n mens kan nie help om tog jou lewe as'n soort van geheel te ervaar nie. So dis nie noodwendig 'n terugkeer nie, maar daar is sekere dinge wat jy nou wil sê en dan moet jy terugkeer na jou werk om te kontroleer - ek kon altyd vir Tim Huisamen gaan vra want hy onthou alles - en besluit om dit óf nie weer sê nie óf op'n ander manier te sê óf te probeer voortgaan daarmee. Daar is ook die amper onvermydelike terugkeer na vroeër wat nie in die eerste plaas met skryf te doen het nie, maar doodgewoon met jou menswees. Vir my is dit die sewentig wat nog altyd 'n baken is waaroor ek baie gemengde gevoelens het. Ek kan hom nog nie mooi beet kry nie. Dit het onvermydelik vir myself ' $n$ noodsaak meegebring om ' $n$ balansstaat op te stel en omdat skryf die manier is waardeur ek in so'n hoë mate lewe, het dit daarheen oorgespring.

Wat sou jy sê is die invloed van jou heel eerste romans soos Lobola vir die lewe en Die ambassadeur op die werk wat jy tans produseer? 
Ek is bly jy sê nie Eindelose weë of Die gebondenes nie!

Watter impak het daardie eerste werk as jy so 'n bestekopname doen? Jy hersirkuleer byvoorbeeld ' $n$ karakter soos Nicolette uit Die ambassadeur; dit was vir my nogal triestig om te sien dat sy ook oud geword het.

Ja dit is, maar dit was deel van waar ek my wou dwing om ook na myself te kyk en te besef Nicolette sou nie jonk gebly het nie. Ek is besig om Stephen Gray se biografie van Beatrice Hastings te lees en daar praat hy van'n ou man van in die 80 wat elke dag na'n sekere plek by die see gaan omdat hy in sy jeug daar'n meisie ontmoet het. Dis nou sestig jaar later, maar hy dink dat sy miskien weer daar sal verby kom en dat hy haar onmiddellik sal herken. Ek wou iets daarvan vir myself ondersoek deur weer te kyk na Nicolette en te ontdek dat ek eintlik op ' $n$ vreemde manier meer geheg is aan haar nou met al haar skete en wondbaarhede en spatare as wat sy toe was.

Om terug te keer na jou eie oeuvre bied jou dus geleentheid om jouself nie net as 'n skrywer nie, maar ook as mens verken?

Ek dink so.

Hierdie is miskien 'n onregverdige vraag, maar is daar sommige van jou vorige romans wat jy sou wou wegskryf of 'doodskryf' as jy kan?

Kyk daar is in elkeen van hulle dinge wat my diep onbevredig laat, selfs erger. Maar op' $n$ ander manier - miskien is dit ook weer' $n$ teken van die ouderdom wat veroorsaak dat ' $n$ mens jouself meer met ' $n$ knippie sout neem of dat jy jouself' $n$ bietjie meer vergewe - besef ek of hulle misluk het of nie, was hulle nodig op'n bepaalde tydstip en as daardie werk nie gebeur het nie, sou ek ook nie verder kon gaan nie. So in daardie sin aanvaar ek hulle - soos Van Wyk Louw sou sê soos ek ook die dood aanvaar.

Daar word heelwat geskryf oor die wyse waarop jy vrouekarakters representeer, maar baie min oor die wyse waarop jy manlikheid of manlikhede representeer. In sekere opsigte veronderstel die kritiek se fokus op vroue in jou werk ook dat manlikheid die verstek-opsie is, die "natuurlike" en "ondeursigtige" posisie wat nie eintlik bespreek hoef te word nie. Tog is dit ' $n$ boeiende onderwerp wat' $n$ mens op verskillende maniere sou kon benader: een van die vrae sou kon wees op watter manier jou agtergrond as Afrikaner jou uitbeelding van 'n verskeidenheid van manlikhede bepaal het. 
Ek dink dit was deurslaggewend; ek dink dit was bepalend. Miskien het ek eintlik te veel as vanselfsprekend aanvaar omtrent die hele verskeidenheid van mans wat ek wel as karakters gebruik het, maar op een of ander manier moes ek hulle almal gepluk het van die boom van my Afrikanerskap af. Ek dink die eerste beeldvorming sou gebeur het in die klein dorpies waar ek groot geword het. Daar was my pa oor wie ek baie ambivalente gevoelens het, want ek verstaan hom nou nog nie naasteby nie. Daar is hele areas in hom wat ek al meer besef ek wens ek het meer daarvan geweet. Soos een ding - ek het dit in Voor ek vergeet ingewerk, maar nie werklik nagevors nie - wat hy gedoen het, toe ons 'n keer op vakansie was: hy het' $n$ hele dag lank nie uit die kamer uit gekom op die plaas waar ons gekuier het nie en my ma het net gesê hy dink. Nou, ek dink hy het sy lewe lank gedink, maar hy het dit nooit so intens gevoel dat hy hom'n dag lank moes afsonder en onttrek nie. Hy was altyd 'n geslote persoon maar hy kon met ander oor die weg kom, hy was nie sosiaal onbedrewe nie. En dan was daar die ou ooms op die plase, die storievertellende ooms wat heer en meester op'n plaas was, soms op afgryslike maniere, soms op wonderlike ruim maniere, soos die oom op wie oom Johnnie in Voor ek vergeet wat vir Chris leer wyn drink gebaseer is. Foeitog, daardie ding het werklik gebeur, want die tante het hom gedwing om die hele wingerd uit te kap nadat hy sy hele lewe bestee het daaraan om van wingerd te leer. Maar daarvandaan was ek gelukkig om met 'n groot verskeidenheid mense in aanraking te kom en op te let en te leer en op te tel om ook ander soorte manlikheid voor te stel. Die eerste beeld is vasgelê deur' $n$ groep Afrikanermans, maar dit is uitgebrei het deur die mans wat ek nou nog ontmoet wat óf ou beelde bevestig óf jou laat besef - soos Jeanne [Goosen] sou sê- ons is nie almal so nie.

Daar word ook dikwels gesê dat sekere karakters in jou werk stereotiep is.

Dink jy 'n skrywer het binne die geheel van 'n romankonstruksie ook stereotiepe karakters nodig?

Ek het dit nodig, al is dit partykeer net om 'n teiken te hê teen wie ek die artillerie kan rig. Maar ek dink ook iets wat'n mens voortdurend ontstel én laat glimlag, is die mate waarin ons - ek weet nie of dit is omdat ek 'n Afrikaner is en meer bewus is daarvan in die Afrikaanse konteks nie - getrou bly aan ons stereotipes. Ten spyte van al die veranderings - en daar het in die Afrikaner-psige oor die afgelope klompie jare verstommende dinge gebeur - is hulle nog daar: jy kan soms nie glo wat jy hoor en sien nie. 
Om vir 'n oomblik stil te staan by literêre tradisie en invloed: jy ken Harold Bloom se Anxiety of Influence waarin hy beweer literêre tradisie is ' $n$ stryd tussen vader-voorgangers en seun-opvolgers. Het jy 'n sterk literêre vader, in Afrikaans of daarbuite, wie se werk jy-om nou Bloom se woorde te gebruik-misgelees het en wat jy wou herskryf?

Ek weet nie of ek bewus is daarvan dat dit in die Bloomiaanse sin so sterk gebeur het nie. Ek weet dat iemand soos - ek is amper verleë om dit te noem, maar dis ook bekend - W.A. de Klerk in my vormingsjare my eerste literêre vader was omdat ek hom leer ken het en omdat ek hom so verskriklik bewonder het. Ek het gedink Die wolkemaker is die grootste roman in Afrikaans, maar op'n gegewe oomblik het die oedipale verwerping tog plaasgevind. Ek sal eintlik'n paar van sy goed weer wou lees, want ek weet hy het my stilisties op'n tyd geweldig en ongelukkig ten kwade beïnvloed. 'n Mens sou miskien ook Camus kon noem, maar ek dink nie ek het ooit so ver gegaan dat ek werklik Camus verwerp het nie. Ek is nog in die oorspronklike seun-vader-verhouding daar vasgevang.

Ek dink 'n mens sou ' $n$ interessante vergelyking kon maak tussen jou en [Breyten] Breytenbach se situasie as jong skrywers. Hy kon in geding of in stryd tree met 'n baie sterk voorafgaande tradisie as jy sien hoe hy Van Wyk Louw parodieer en herskryf in sy vroeë werk. Vir'n romanskrywer was dit miskien ' $n$ ander soort situasie omdat die romantradisie daar anders uitgesien het.

Ja, ons het nie werklik vaders gehad na wie ons genoeg opgesien het om hulle te wou verwerp nie.

Hoe voel dit dan om later self in daardie vaderposisie te wees vir iemand

soos Dan Roodt wie se Moltrein so sterk heenwys na Die ambassadeur? Wel, ek dink Dan het in elk geval van die begin af so neerhalend en verwerpend teenoor my gestaan dat dit nie voel asof ek werklik'n vader was nie.

Maar verwerping is tog die gevolg van die feit dat jy wel' $n$ sterk rol speel as vaderfiguur?

Ja, ek sien dit op verskillende maniere in die jonger generasie wat my dan elke keer laat besef ek is in daardie generasie waar die verwerping nou moet begin deurwerk. Ek dink tot dusver is ek nog eerder half benieud, half geamuseerd daaroor; ek is nog nie baie ontsteld nie en ek dink in party opsigte is ek eintlik onverdiend gelukkig dat daar nog 
altyd ten minste onder die jonges sommiges is wat nie by die verwerping gekom het nie. Ek het eintlik al in die jare sewentig daaroor geskryf dat ons moet besef ons beurt sal kom en dat daar ander generasies moet kom. Ek dink ek het dit toe meer gesien in terme van die opeenvolging en nie soseer van die verwerping van die voorafgaande wat daarmee moet saamhang nie. Maar ek dink dit is basies'n gesonde verskynsel. Dit is nie só lekker as dit' $n$ mens self tref nie, dit kan ek my goed indink, maar tot dusver het dit genadiglik nog nie te sterk gebeur nie.

Jy word liefs en by herhaling uitgeora oor die rol van die seksuele in jou werk soos wat nou ook weer die geval was met die verskyning van Voor ek vergeet. Vir my lyk dit egter asof begeerte eintlik'n groter dryfueer is as die seksuele in jou later werk, asof die konsumasie van seksuele begeerte meestal uitgestel word. Dit lyk asof die seksuele wat in die vroeër werk uitgebeeld is as die moment van ultieme vryheid of transendensie eintlik vervang is ek spekuleer nou - met die nosie van begeerte wat in die Lacaniaanse sin eintlik in wese onvervulbaar is. Sou jy sê dit is wel so?

Ek het nog nie spesifiek so gaan sit en dink daaroor nie, maar ek dink jy's absoluut met jou vinger daarop. Ek weet nie of dit nog 'n onvermydelike deel van die ouer-word proses is nie. Eerstens ontdek'n mens dat daar baie meer kante aan die seksuele ervaring is as wat' $n$ mens in jou jeug gedink het. Tweedens het dit gebeur omdat begeerte so' $n$ fassinerende konsep is in terme van seksualiteit, maar ook - soos 'n mens via Kristeva en al daardie mense weet - in die voortbring van literatuur, in die hele kreatiewe impuls. Ek dink eintlik dat dit skryf, of kuns-skepping in die algemeen, in die wiele sou ry as vervulling maar 'n gegewe was; ek dink dit is miskien die eintlike dryfveer, ja.

My eie ondervinding as leser is dat ek heeltemal meegevoer kan raak deur 'n storie, maar soms'n gevoel van teleurstelling of antiklimaks ervaar as dinge afgewerk of gesluit word, soos byvoorbeeld in 'n speurverhaal. Ek is eerder gefassineer deur daardie werke waarin daar nie werklik'n vervulling of closure bereik word nie.

Dit is die impuls agter die hele Duisend en een nagte wat vir my dié sleutelwerk van die hele vertelkuns bly. Dit is eintlik'n teleurstelling wanneer jy by die duisend-en-eerste nag kom en Sjeherazade dan vir haar sussie vra om die twee of drie kinders in te bring om aan Sjahriar te wys wat hulle voortgebring het in die duisend en een nagte. Jy voel: is dit nou maar al waarom dit gegaan het? Wat my betref, is dit die 
afwagting, onvervuldheid, onvervulbaarheid van die begeerte wat die skryfproses aan die gang hou. Dit is amper soos die soort angs wat' $n$ mens tref wanneer jy'n werklike lang roman lees - ek het dit nog nooit so sterk soos met Sigrid Undset se Kristin Lavransdattir gevoel nie - en skielik die angs wat jou pak as jy sien die blaadjies raak nou min hier na die end toe. Jy moet stadiger begin lees, want jy wil nie daar uitkom nie. Fuentes het 'n wonderlike essay geskryf oor die verhouding daartussen en die lewe en die dood; jy wéét van die dood wat aan die einde kom.

Watter van die tekste wat jy geskryf het, lê jou die naaste aan die hart? Dit is altyd vir my die moeilikste van alle vrae.

Ek weet, ek weet: watter een van jou kinders het jy die liefste, dis 'n gruwelike vraag. Sê maar as jy dit nie wil beantwoord nie.

Daar is verskillende maniere waarop ek elkeen van hulle nie kan verdra nie en daar is verskillende maniere waarop ek miskien die gebreklike kinders die liefste het omdat hulle die meeste koestering nodig het. Maar ek dink ek het nog steeds'n soort sentimentele verknogtheid aan ' $n$ Oomblik in die wind en aan Houd-den-Bek. En daarom ook aan die nuwe een, Bidsprinkaan, wat ek nou net afgelewer het, want dit gaan terug na daardie soort wêreld toe.

Is dit weer' $n$ historiese roman?

Dis histories: dis die ou Afrika-wêreld van die Khoi-San vermeng met die Christelike, die eerste Hottentot-sendeling aan die Kaap wat verwerp is deur sy mense (sy mense, synde die Londense Sending Genootskap). So daardie twee sou ek miskien tog sê koester ek nog.

Met die onlangse herlees van daardie twee romans is ek opgeval deur die geweldige energie daarvan, 'n soort van 'n vitaliteit wat uit daardie konfrontasie met die geskiedenis spreek.

Daar is ten spyte van al die geweld en donkerte ook humor in. Dit is miskien hoekom ek tog ook Kennis van die aand daarby sou kon plaas.

Vir my is Inteendeel ' $n$ gunsteling.

Dit is nogal dink ek redelik oor die hoof gesien; ek het verskriklik lekker gewerk daaraan. Ek dink daar is min stukkies geskiedenis wat ek teëgekom het waar dit so op'n skinkbord gegee is dat die man homself in sy lewe, in sy briewe aan die goewerneur elke keer herontwerp het 
en'n nuwe identiteit aangeneem het. So'n mens kon maar net voortdig op die ou rympie.

Lees jy baie geskiedenis? Hoe kom jy op die historiese onderwerpe af wat jy in jou romans verwerk?

Ek is gewoon gedrewe deur begeerte vandat ek in standard sewe was en'n ongelooflike geskiedenis-onderwyser gehad het wat my'n passie daarvoor gegee het. Hy het ook begin om vir my verskillende boeke te bring wanneer ek sê maar besig was om oor die Egiptenare of iets te lees sodat ek kan sien al die boeke vertel nie die storie op dieselfde manier nie. Dit het my beetgeneem op universiteit. Ou D.W. Kruger op Potch was ook ongelooflik om 'n mens te probeer stuur na die bronne toe, in die mate wat die bronne nou op Potch toeganklik was. Ook later toe ek in die argief kon werk en daardie ou blaaie kon hanteer en besef hier het die man met sy eie hand dit geskryf, daardie getuienisse van Houdden-bek: dit was net' $n$ ongelooflike ondervinding. Ek het net' $n$ hartstog daarvoor en ek hou aan om dit te lees, maar daar was ook oor die jare mense wat my spesifiek gehelp het. Ek kan onthou dat ek, nadat ek Josef Malan se geskiedenis in Kennis van die aand geskryf het, begin soek het na'n slawe-opstand; ek het net gevoel daar is iets wat ek nodig het vir wat ek wil sê. Ek het met verskillende mense oor die jare daaroor gepraat en toe't Herman Giliomee vir my gesê hy het iets gekry wat ek miskien kan gebruik. En sedertdien is daar Nigel Penn wat baie werk oor die hele Weskus-gedeelte op na die noordgrens toe. Af en toe kom hy met so'n glimlaggie en sê: "I think I've got something you would like". En dit vind ek geweldig stimulerend. 